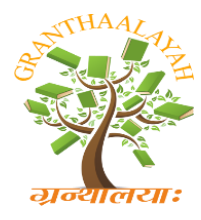

\author{
INTERNATIONAL JOURNAL OF RESEARCH - \\ GRANTHAALAYAH \\ A knowledge Repository
}

Social

\title{
ST. GEORGE'S CATHEDRAL, CHENNAI CHURCH OF THE CITY A STUDY IN RELIGION AND ART
}

\author{
Ms. H. Rasi ${ }^{* 1}$ \\ ${ }^{* 1}$ Ph.D., Assistant Professor of History, Sri Parasakthi College for Women, Courtallam, INDIA \\ DOI: https://doi.org/10.29121/granthaalayah.v4.i10(SE).2016.2465
}

\begin{abstract}
Built in the heart of Chennai in A.D. 1815, and consecrated to the service of God on 6 January $1816^{1}$, St. George's Cathedral is an imposing structure - an oasis of peace and tranquillity - reminding us the presence of God every moment of our life. Rt. Rev. T.F. Middleton, the first Anglican Bishop in India inaugurated the church, and thought the new church was "handsomer than anyone in England". The Cathedral is a symbol of the sufferings, the struggles, and ultimately the success of Christianity in South India, especially Tamil Nadu.
\end{abstract}

Keywords:

St. George's Cathedral, Church, Religion, Art.

Cite This Article: Ms. H. Rasi, “ST. GEORGE'S CATHEDRAL, CHENNAI CHURCH OF THE CITY A STUDY IN RELIGION AND ART" International Journal of Research Granthaalayah, Vol. 4, No. 10: SE (2016): 25-29.

\section{INTRODUCTION}

Planned by Sir J.L Caldwell, an engineer of the English East India Company, the construction was completed by his assistant Major de Havilland. Named after St. George, the patron saint of England $^{3}$, the Cathedral has grown in strength and stature over the years, and has gained the distinction of being described as "the Church of the City". It was in the sacred precincts of this Cathedral the ecclestical barriers between Protestants of different denominations - Anglican, Methodist, Presbyterian, and Congregational - were done away with, the schism in the church healed, and the Church of South India (C.S.I) inaugurated in $1947^{4}$. This was a historic occasion, a demonstration of the unity of the Protestants of South India. St. George's Cathedral assuming unprecedented leadership, informing that all Protestants are the offspring of the same mother, and an instilling awareness among them that they draw their sustenance from the same source, has earned for the Cathedral the title "Mother Church", Mother Church of the Diocese of Madras. 

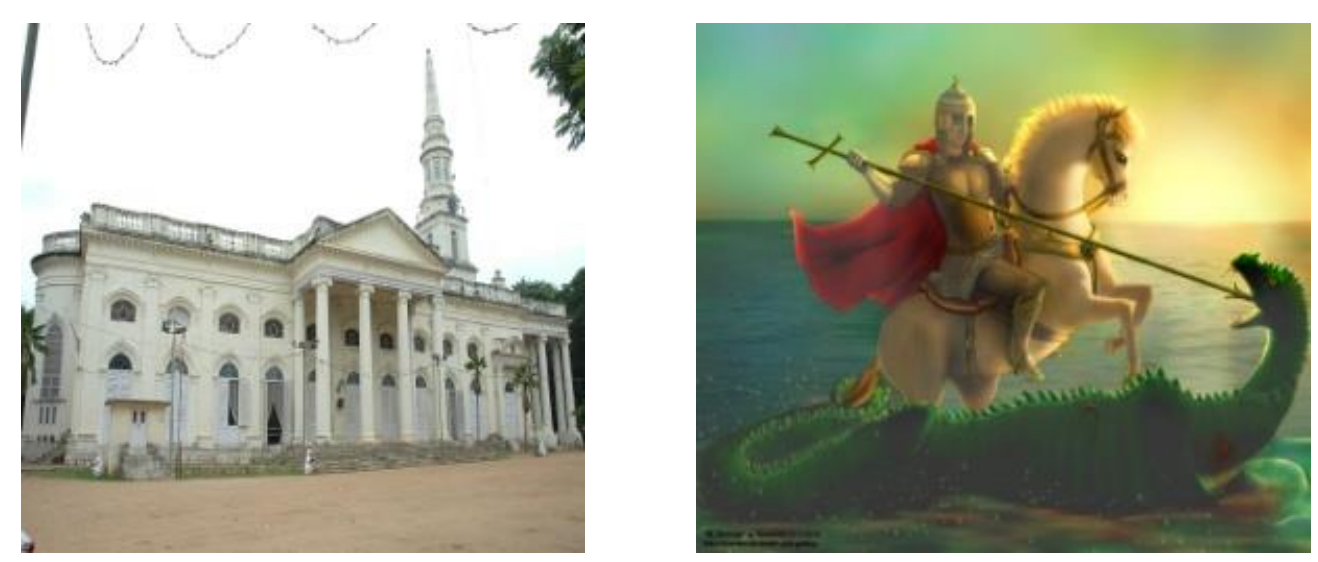

A chronicler of the Cathedral describes St. George's as "a massive and majestic piece of architectural grandeur". The facade of the church is awe - inspiring. It is said that "the facade and frontage bear strong resemblance to St. Martin's in-the- Field in London". The huge pillars have Ionic capitals; the steeple is 139 high; there are trees in the periphery, old with age; flowering plants and creepers lend colour and beauty to the landscape. The Altar of the Cathedral is majestic; sun light passes through the stained glass panels, and bathes the Altar in a blaze of colour. Behind the Altar is a depiction of the execution of Jesus Christ sculpted in alabaster "at the top of which stands a black marble statue of St. George, the patron saint of England". Quite flittingly, the cathedral has adopted Raphael's painting of St. George slaying a dragon as its $\log _{0}{ }^{6}$. The lectern has a large brass eagle with its wings spread and beak open. Even the cemetery with a Gateway looking like a lotus in a pond has a solemn and silent dignity of its own; dry leaves and dead wood cover the cemetery like a decayed carpet. The clock in the turret is a period piece. Music from the church bells merge with wind and waves, and assure the faithful that they are always in God's mind and memory. What is unique about St. George's Cathedral is people's participation in building and beautifying the church. History is replete with examples of states and sovereigns building places for public worship. But St. George's was raised by "the people themselves".

Four walls and a flat roof alone do not make a church. Fixtures and fittings, furniture, ritual paraphernalia, and a host of such artefacts make the church attractive, elegant, dignified - here too the people gave. The Altar Cross was donated by Surgeon-General Cornish, the altar table by De La Fond, the altar rail by P.Orr and Sons, and the Episcopal chair by F.E. Kneale; the Bishop's throne, the Litany stool, and the clergy seats were carved by W.S.Whiteside, the gold chalice set with diamonds in the form of a cross and paten for Holy Communion (they weigh 1.6 $\mathrm{kg}$ in 18 carat gold) were a gift of Lt. Col. Herbert St. Carruthers. The marble baptism font was donated by the congregation. The lectern was a memorial tribute to Archdeacon Warlow by his friends". The bells were presented by Banbury, and the Chiming device by Rev. Thomas Foulkes. The turret clock is a gift of the Directors of the Hon' ble East India Company. "The guardrail of the old cemetery is made up of war insignia including muskets and bayonets that date back to the capture of Seringapatnam in $1799^{7}$ ". I was sadly disappointed when I searched to find this fantastic piece of history in the cemetery; no trace of the rail could be seen anywhere. A church historian informs that the guard rail disappeared over the years due to theft ${ }^{8}$. Historical artefacts vanishing from their site due to vandalism or being obliterated due to ignorance have to be protected at all costs. Since so many men and women from far and near have willingly 
participated in raising the church and embellishing it like a jewel, I am tempted to describe the church as a "People's Church".

The stained glass panels of the Cathedral in the altar are a marvel. The panel on the left depicts the Baptism of Jesus by John the Baptist, and the one on the right the resurrected Lord with Mary Magdalene; the two panels belong to the best artistic tradition in the world and are priceless treasures. The sun light passing through the medium of glass finds its way into the altar and covers it in all the colours of the rainbow. There are stained glass windows above all the doors of the Cathedral; but there is nothing dramatic about them. They do not tell stories and do not impress the viewer in any special way as the same design is repeated again and again, but the fact remains that they too are multi-coloured and succeed in spreading sunshine all over the Cathedral.

H.S.S. Lawrence invites our attention to the eight large musical bells manufactured by Mears and Steinbanks, Founders, London, and installed in the cathedral in 1873,

All the eight bells vary in size. The height of the largest bell is $42^{\prime}$, its diameter $48^{\prime}$ and its circumference $150^{\prime}$ approximately. The smallest bell is $24^{\prime}$ in height, $30^{\prime}$ in diameter and approximately $94^{\prime}$ in circumference. Theses bells were installs inside the central portion of the pinnacle below the clock and about $50^{\prime}$ above the ground level.... the bells continue to chine day in and day out. ...

The bells seem to be an amazing musical device, the like of which not seen in many places.

The Cathedral has a spacious cemetery in its south-eastern corner with a renovated Gateway. Elizabeth de Havilland (1818), wife of Major de Havilland who constructed the Cathedral, was the first to be buried in its cemetery in 1818. It has been said of her that "she stood highly respected, and, in the social duties of wife, mother, daughter, sister, and friend, she shone with superior virtue". ${ }^{11}$ The cemetery also contains the grave of the Rt. Rev. T. Dealtry (1861) who laboured in India "with singular fidelity and unsparing devotion"12 Dr. H. Harris (1822), "the great linguist and an authority on the Hindi spoken in the Deccan", also lays buried in the same cemetery. 13

The St. George's Cathedral, incidentally, is also an archive - archives in marble and metal. Marble statues and mural tablets strewn all over the cathedral are treasure chests of history. The services and sacrifices of bishops and archbishops, scholars and statesmen, missionaries and military commanders - "men who made a difference in the lives of the people in India" - are recapitulated in these monuments. ${ }^{14}$

The tribute engraved below the statue of Judge C.H. Higginson (1824) speaks of him as "a pious and dutiful son, an attached and affectionate husband, a kind and generous master, a warm and sincere friend. Higginson's monument by C.H.Smith shows him holdings a copy of Manu "On Laws". The monument has been raised by his friends who considered him "one of the best of men" 
An inscription under the statue of W. Parry (1824), founder of the house of Parry \& Co in 1795, says that "in his were happily united those qualities which elevate and adorn the human character" and that he "endeared him (self) to the native and European inhabitants". ${ }^{16}$ The company founded by W. Parry two hundred years ago prospered, and has become an arbiter of the economy of Tamil Nadu.

The unusual figure shown in the sculpture in memory of Assistant Surgeon J. Mack (1832) represents not the figure of the surgeon but of Hygeia, the goddess of health, offering an oblation to a serpent...." Dr.Jack was "surgeon to the Governor's Body Guard and Physician to the Durbar of His Highness the Nawab of the Carnatic". 18

Rt. Rev. Daniel Corrie (1837), the first Bishop of Madras, is represented by a life -size figure sculpted by Weekes. He is shown in his robes and with a Bible in one hand, the other hand resting on the shoulder of a native boy. The inhabitants of Madras who have created the monument mention in the memorial his manifold services to promote the cause of the church and the society. The editor of the inscription observes: "His name will be handed down to posterity in the Madras Presidency in connection with Bishop Corrie's grammar school, which he founded and still bears his name; the oldest purely educational institution in the city". ${ }^{19}$ His mortal remains rest in peace in the cathedral's cemetery with a modest mention of his name and positions held in the church.

Justice J.D. Norton (1843) is remembered in a marble tablet. He is described as "a man exemplary in every relation of life, a lover of all that is good and beautiful and true". ${ }^{20}$ The judge died on board the Castle Eden and buried at sea.

A few of the medical brethren of W. Griffth (1845), "one of the most distinguished Botanists of the age" have erected a tablet in his memory. "His collections number as many as 9,000 species, which is by far the largest number ever obtained by individual exertions. There is a monument to him in the Botanical Garden at Culcutta". ${ }^{21}$ The inscription informs: "His early death... elicited a public and emphatic expression of regret from the Governor-General of India"

Rt. Rev. T. Dealtry (1861), Bishop of Madras, who had the distinction of ordaining 151 clergymen, is seen blessing two young priests. ${ }^{22}$ Durham was the sculptor who made the monument.

N.R. Pogson (1891), for whom there is a memorial in the Cathedral, was Government Astronomer at Madras for 30 years. "By his valuable contributions to Astronomy and by his discoveries and observations of stellar phenomena... he earned an enduring name". The editor of the inscription adds: He discovered twenty new variables of stars and ten new minor planets...."23

The cathedral contains a tablet to cherish the memory of Rt. Rev. R. Caldwell (1891), a Fellow of the University of Madras. He excelled

as a scholar and philologist, intimately acquainted with the Tamil people, their history, language and religion, and customs, bringing honour thereby to the missionary's calling 
.... brought thousands of heathen into the church of Christ, raised the character and status not of the Christians only, but also of those without the church.... ${ }^{24}$

The memory of District Collector and Magistrate of Tinnevelly, R.W.D. Ashe (1911) is mentioned in a tablet. The tablet does not omit to mention that Ashe was "killed by the hand of political assassin". 25

Apart from religious work, the Cathedral has started identifying itself with the community around which it functions, and has started projects and programmes for secular welfare. The Community Welfare Centre (with a Sewing School, a Typewriting Institute, a Day Care Centre, a Medical Clinic), Leprosy Project, Green Pastures (looking into ecological concerns), Home for Senior Citizens are among the many faces of St. George's Cathedral. I am sure that the congregation, the Trustees, the Bishop, in fact everyone concerned with the cathedral - believe that love of man is equal to love of God, and will do everything that lies in their power to improve the quality of life around them, and ensure that the will of God is done.

\section{REFERENCES}

[1] H.S.S.Lawrence, St.George's Cathedral, Chennai, 2007, p.4

[2] J.J.Cotton, List of Inscriptions on Tombs or Monuments in Madras,

[3] Government Press, Madras, 1945, p.97

[4] H.S.S.Lawrence, op.cit., p.6

[5] Rajalakshmi Theodore, Anglicanism in Madras, C.L.S, 2006, p.132

[6] Ibid., p.124

[7] H.S.S.Lawrence, op.cit., p.16

[8] Ibid., p.5

[9] Rajalakshmi Theodore, p.125

[10] H.S.S.Lawrence, op.cit., p.17

[11] H.S.S.Lawrence, op.cit., p.19

[12] J.J. Cotton, op.cit., p.117

[13] Ibid., p.128

[14] Ibid., p.120

[15] St. George's Cathedral's Pamphlet, p.2

[16] J.J. Cotton, op.cit., p.99

[17] Ibid., p.100

[18] Ibid., p.102

[19] Ibid., p.103

[20] Ibid., p.104

[21] Ibid., p.106

[22] Ibid., p.107

[23] Ibid., pp.111-112

[24] Ibid., p.114

[25] Ibid.

[26] Ibid., p.116 